\title{
Case Studies in Religious Education
}

\author{
Mehmet Okutan \\ Karadeniz Technical University, Fatih Faculty of Education, Educational Sciences, Educational \\ Administration Inspection Planning Economics, Trabzon, Turkey \\ E-mail: mehmetokutan@ktu.edu.tr
}

\begin{abstract}
The case study method is known in our culture as almak taking shares from the story ", which means" story, narration, event, narration, narration style.. The case study method is used both as a research model and as a teaching method. The case study method was first put into practice at Harvard University School of Business in the 1920s and has been used frequently as a teaching method. Case study is known as a frequently used method in teaching today. The case study method used in teaching is known as a method in which real life problems are discussed in the classroom and solutions are proposed. This method, which requires students to actively participate in a problematic event, is possible to bring many of the subjects into the classroom in the form of case studies and examine them, especially in the social sciences and in religious education. The case study method in educational research is able to easily show the causes and the problems of the problems, incidents that arise in the educational applications. This method allows the real and objective revelation of the problems that arise in the education system. The case study method, which is suitable for in-depth understanding of the problems that arise in education, is also suitable for providing important clues about teachers' teaching leadership. Realistic information on the quality of teachers is likely to be achieved through case studies.

The aim of this study is to reach detailed information about what religious teaching is and how it is applied by starting from the practices of teachers who carry out religious teaching.

This objective was tried to be achieved through case study method. The research was conducted on 4 case studies related to religious culture ethics course. These case studies were interpreted with the findings of educational sciences.

The results of this research show that teachers of religious culture ethics have developed teaching styles that do not coincide with the findings of contemporary educational sciences. One of the most important results of these case studies is the fact that fear is dominant in religious teaching.
\end{abstract}

Keywords: Religious Education, Education, Case study method

DOI: $10.7176 / \mathrm{JSTR} / 5-9-08$

\section{Din Öğretiminde Örnek Olaylar}

\begin{abstract}
Özet
Örnek olay yöntemi kültürümüzde "kıssadan hisse almak" tabiri ile bilinen, "hikâye, rivayet, olay, anlatış, anlatış tarzı" anlamına gelen bir yöntemdir. Örnek olay yöntemi, hem araştırma modellerinden biri, hem de öğretim yöntemlerinden biri olarak kullanılmaktadır. Örnek olay yöntemi, bir öğretim yöntemi olarak ilk defa 1920'li yıllarda Harvard Üniversitesi İşletme Okulu'nda uygulamaya konularak günümüze kadar çok sıkça kullanılagelmiştir. Örnek olay çalışması, öğretimde günümüzde sıklıkla kullanılan bir yöntem olarak bilinmektedir. Öğretimde kullanılan örnek olay yöntemi, gerçek hayatta karşılaşılan problemlerin, sınıf ortamında tartışılarak, konuya ilişkin çözüm önerilerinin geliştirildiği bir yöntem olarak bilinmektedir. Öğrencilerin sorunlu bir olaya aktif olarak katılmalarını gerektiren bu yöntem, özellikle sosyal bilimlerde, bu arada din eğitiminde de pek çok konunun, örnek olay biçiminde sınıfa getirilip, incelenme firsatı yakalanması mümkündür. Eğitim araştırmalarında örnek olay yöntemi, eğitim-öğretim uygulamalarında ortaya çıkan sorunların, olayların, nedenlerini ve nasıllarını kolayca gösterebilecek niteliktedir. Bu yöntem, eğitim sisteminde ortaya çıkan sorunların gerçek ve nesnel bir şekilde açığa çıkmasına firsat verir. Eğitimde ortaya çıkan sorunların derinlemesine anlaşılmasına uygun bir yöntem olan örnek olay yöntemi, öğretmenlerin öğretim liderliği konusunda önemli ipuçları vermeye de
\end{abstract}

54 | P a g e

www.iiste.org 
uygundur. Öğretmenlerin kalitesi ile ilgili gerçekçi bilgilere, örnek olay yöntemi ile ulaşma ihtimali yüksektir.

$\mathrm{Bu}$ çalışmanın amacı, din öğretimini yürüten öğretmenlerin uygulamalarından yola çıkarak, din öğretiminin ne olduğu, nasıl uygulandığı konusunda ayrıntılı bilgilere ulaşabilmektir.

Bu amaca örnek olay yöntemi marifetiyle ulaşılmaya çalışıldı. Araştırma, din kültürü ahlak bilgisi dersi ile ilgili 4 örnek olay üzerinden gerçekleştirildi. Bu örnek olaylar, eğitim bilimlerinin bulguları ile yorumlanmaya çalışıldı.

$\mathrm{Bu}$ araştırma sonuçları, din kültürü ahlak bilgisi öğretmenlerinin, çağdaş eğitim bilimleri bulguları ile örtüşmeyen öğretmenlik tarzları geliştirdiklerini göstermektedir. Bu örnek olayların ortaya koyduğu en önemli sonuçlardan biri, din öğretiminde sevgi değil, korkunun egemen olduğu gerçeğidir.

Anahtar Kelimeler: Din Öğretimi, Eğitim, Örnek olay yöntemi

\section{Giriș}

Okul denilen formal bir örgütte gerçekleştirilen eğitim-öğretim, daha çok sınıf denilen alt örgütlerde gerçekleştirilmektedir. Okul denilince hemen aklımıza sınıfın geldiğini de biliyoruz. Belli bir yerde toplanarak, bir veya birkaç öğretmenin gözetimi ve yönetimi altında ders gören öğrenci kümesi(Oğuzkan 1981) biçiminde tanımlanan sınıf, genellikle her derste, farklı alan(branş) öğretmenleri tarafından değerlendirilir. Bu durum, öğrencinin farklı öğretmenlerce gözetlenip yönetildiği anlamına gelmektedir. Farklı alanlar diye belirtilen alanlardan biri de din eğitimini vermekle yükümlü öğretmenler olan, din kültürü ve ahlak bilgisi öğretmenleridir. Öğretmenlerin hepsi 1739 sayılı Milli Eğitim Temel Kanunu'nda belirtilen "alan bilgisi, öğretmenlik meslek bilgisi(pedagojik formasyon) ve genel kültür" yeterliklerini haiz olmaları beklenir. Denilebilir ki, ögretmenlerin hepsi bu yeterliklere az ya da çok sahiptirler. Ne var ki, din kültürü ahlak bilgisi öğretmenlerinin milli eğitim camiasında daha farklı bir yere konumlandırıldığını biliyoruz. Bu durum bazen onların lehine, bazen de aleyhine olarak değerlendirilebilmektedir. Bu alanın öğretmenleri bazen "hoca" ya da "dinci” diye adlandırılarak diğer öğretmenlerden farklılaştırılmak istendiği de bilinen gerçeklerdendir.

Bilgi çağının öğretmenleri olarak bütün öğretmenlerin olduğu gibi, din kültürü ve ahlak bilgisi öğretmenlerinin de bilgi çağı okulunun öğretmenleri olmaları için, çağın gerektirdiği donanıma sahip olmaları bir zorunluluktur. Bu çağın öğretmeni her şeyden önce "lider öğretmen" olmakla yükümlüdür. Ayrıca bilgi çağının öğretmeni, bilginin değişen doğasına uygun bir öğretmenlik formasyonuna sahip olmak zorundadır. Bilgi çağının öğrencisi, öğretmenlerin ne anlattıklarına değil, nasıl anlattıklarına bakarak, öğretmenlerini değerlendirecektir. Öğrencilerin değerlendirmelerinden yeterli puanı alamayan öğretmenler, yetersiz öğretmenler olarak yaftalanmayı hak edeceklerdir. Bilgi çağının öğrencisi, "Öğretmenin dediğini yap, yaptığını yapma" sözüne şöyle karşılık verecektir: "Hayır sen ne yapıyorsan, ben de onu yapacağım". Öyleyse bütün alan öğretmenleri(din kültürü ve ahlak bilgisi öğretmenleri de), öncelikle, söylemleri ile davranışlarının aynı olmasına dikkat etmek zorunda kalacaktır. Söylemleri ile davranışların aynı olması bütün öğretmenler için zorunluluktur, ancak din öğreten öğretmenler için çok daha zorunluluktur. Çünkü din öğreten öğretmenler, davranışları ile dine uygun bir model olmak yükümlülüğ̈̈ne sahiptir. Allah Resulü(S.A.) öğretmen(muallim) olarak gönderildiğgini bildirerek, bir taraftan dinin temel esaslarını ögretiyor, bir taraftan da bildiklerini yaşantısına yansıtarak örnek oluyordu. $\mathrm{Bu}$ örnek, onun "numune-i imtisal"(rol model" olarak bilinmesi ve tanınmasına neden oluyordu. Günümüzde onun öğrettiklerini öğretip, soyut bilgilerin davranışları ile örnek olması gerekenlerin başında, dini öğretmekle yükümlü olan din kültürü ve ahlak bilgisi öğretmenleri gelmektedir. Allah Resulü' nü(S.A.) bilgi ve davranışlarıyla örnekleyecek olanların başında din kültürü ve ahlak bilgisi öğretmenlerinin geldiği akıldan çıkarılmamalıdır. Bu bakımdan, din kültürü ve ahlak bilgisi öğretmenleri, yetişmekte olan çocuk ve gençlerin "numune-i imtisalleri" olmak zorundadır. Günümüz eğitim bilimleri terimlerinden biri olan "rol model" kültürümüzde "numune-i imtisal" "usvetünhasene" olarak bilinmektedir. Rol model ve numune-i imtisal olmak göründüğü kadar kolay değildir. Bütün zorluğuna rağmen, din kültürü ve ahlak bilgisi öğretmenlerinin bu rolü oynamaları ve diğer öğretmenlere de rol model olmaları beklenir.

\section{Amaç}

$\mathrm{Bu}$ çalışmanın amacı, din öğretimini yürüten öğretmenlerin uygulamalarından yola çıkarak, din öğretiminin ne olduğu, nasıl uygulandığı konusunda ayrıntılı bilgilere ulaşabilmektir. Başka bir ifade ile bu çalışmanın amacı, din öğreten din kültürü ve ahlak bilgisi öğretmenlerinin, öğretmenlik niteliklerini anlamaktır. 


\section{Yöntem}

Bu amaca "örnek olay” yöntemi marifetiyle ulaşılmaya çalışıldı. Araştırma, din kültürü ahlak bilgisi dersi ile ilgili 4 örnek olay üzerinden gerçekleştirildi. Bu örnek olaylar, eğitim bilimlerinin bulguları ile yorumlanmaya çalışıldı. Bu oturumda din kültürü ve ahlak bilgisi öğretmenlerinin öğretmen-öğrenci ilişkileri, bu örnek olaylardan yola çıkılarak tartışılacak ve sorunun çözümüne ilişkin öneriler üzerinde durulacaktır.

Örnek olay yöntemi kültürümüzde "kıssadan hisse almak" tabiri ile bilinen, "hikâye, rivayet, olay, anlatış, anlatış tarzı" anlamına gelen bir yöntemdir. Örnek olay yöntemi, hem araştırma modellerinden biri, hem de öğretim yöntemlerinden biri olarak kullanılmaktadır. Örnek olay yöntemi, bir öğretim yöntemi olarak ilk defa 1920'li yıllarda Harvard Üniversitesi İşletme Okulu'nda uygulamaya konularak günümüze kadar çok sıkça kullanılagelmiştir. Örnek olay çalışması, öğretimde, günümüzde sıklıkla kullanılan bir yöntem olarak bilinmektedir. Öğretimde kullanılan örnek olay yöntemi, gerçek hayatta karşılaşılan problemlerin, sınıf ortamında tartışılarak, konuya ilişkin çözüm önerilerinin geliştirildiği bir yöntem olarak bilinmektedir. Öğrencilerin sorunlu bir olaya aktif olarak katılmalarını gerektiren bu yöntem, özellikle sosyal bilimlerde, bu arada din eğitiminde de, pek çok konunun, örnek olay biçiminde sınıfa getirilip, incelenme firsatı yakalanması mümkündür. Eğitim araştırmalarında örnek olay yöntemi, eğitim-öğretim uygulamalarında ortaya çıkan sorunların, olayların, nedenlerini ve nasıllarını kolayca gösterebilecek niteliktedir. Bu yöntem, eğitim sisteminde ortaya çıkan sorunların gerçek ve nesnel bir şekilde açığa çıkmasına firsat verir. Eğitimde ortaya çıkan sorunların derinlemesine anlaşılmasına uygun bir yöntem olan örnek olay yöntemi, öğretmenlerin öğretim liderliği ya da geleneksel öğretmen oluşları konusunda önemli ipuçları vermeye de uygundur. Öğretmenlerin kalitesi ile ilgili gerçekçi bilgilere, örnek olay yöntemi ile ulaşma ihtimali yüksektir. Bunun için, sınıf yönetimi dersinin işlenmesi esnasında, her öğrencinin, bir öğretmen-öğrenci ilişkisini örnekleyen örnek olayı, derste sunma çalışması yaptırılmıştır. Örnek olay, gerçek kişilerce yaşanmış alayların rasyonel olan ve olmayan yönleriyle öğrenme ortamına yansıtılması(Güçlüol 1985: 68) biçiminde açıklanabilir. Bu yöntem öğretimde ortaya çıkan öğretmenöğrenci ilişkilerinin nedenleri ve nasıllarını daha kolay göstermeye uygundur(Karasar 1991: 86). Örnek olay yöntemi gerçeklerin nesnel bir şekilde açığa çıkmasına yardım edebilir(Nisbet \&Watt 1984:123). $\mathrm{Bu}$ yöntem bir eğitim-öğretim uygulamasına ilişkin bilgi ve beceriyi doğrudan öğretmeyi amaçladığından, sınıfta yapılacak başka tür uygulamalardan daha fazla etkili olabilir.

Sınıf yönetimi/eğitim yönetimi dersinde örnek olay uygulaması sürecinde şu aşamalar izlenmiştir:

*Her öğrencinin, kendi başından geçmiş bir olayı hikâye olarak okuması veya anlatması,

*Bu olaydaki istenmeyen öğrenci veya öğretmen davranışının irdelenmesi, tartışılması,

*Örnek olaydaki öğretmenin istenmeyen öğrenci davranışını yönetme biçiminin değerlendirilmesi,

*Örnek olayın öğretim üyesinin rehberliğinde tartışılması,

*Son olarak da, "Siz öğretmen olsaydınız ne yapardınız?" sorusunun sınıfa sorulup, yeterli geri bildirip alındıktan sonra öğretim üyesinin sunuyu özetlemesi

\section{ÖRNEK OLAY 1}

\section{Kelime-i Şehadet Getiremeyen Öğrencinin Cezası}

İlkokul 4. Sınıftaydı. Öğretmen bu derste din kültürü ve ahlak bilgisi dersi işleyeceğini söylemişti. Öğretmen din dersi anlatmaya başlamıştı. Sonra oturduğumuz sıraya göre, herkesi sırayla tahtaya kaldırmaya başladı. Tahtaya kalkan öğrencilerden kelime-i şehadet getirmesini istiyordu. Bir harf hatası bile olsa, öğretmen sinirlenip bağırıp çağırıyor, kelime-i şehadeti getiremeyeni kapının önünde ayakta sıraya diziyordu. Eksiksiz söyleyebilenler yerlerine oturuyordu. Bir ara öğretmen sınıftan çıktı, biraz sonra tekrar sınıfa döndü. Arkasında okulun hizmetlisi, elinde koca bir sopa ile sınıfa geldi. Sopayı öğretmene uzattı. Öğretmen sinirlenerek bağırıp çağırmaya devam ediyordu. Ayakta duran öğrencilere; "Parmaklarınızın uçlarını birleştirerek uzatın," dedi.

Öğretmen sırayla ellerini uzatan öğrencilerin parmak uçlarına vurmaya başladı. Bir arkadaşımızın kafasına vurmaya başladı. Sopanın çivili yeri arkadaşımızın kafasına geldiği için kanamaya başladı. Hademeyi çağırdı ve kanayan yerin tendürtiyotla silinmesini ve bantlanmasını emretti. Kendisi hiçbir şey yapmıyordu. Sınıfta büyük bir sessizlik vardı. Öğretmen durumun hiç umurunda değildi; hiçbir şey olmamış gibi derse devam etmeye çalışıyordu. Öğrenciler, dinin öğretilerinin zorla nasıl öğretilemeyeceğini bu olayla çok iyi anlamışlardı.

Bu olayda din kültürü ve ahlak bilgisi dersi ile ilgili "bilgi eksikliği”, istenmeyen öğrenci davranışı olarak değerlendirilmiştir. Öğrencinin kelime-i şehadeti getirememesi davranışı, istenmeyen davranış olarak değerlendirilmiş ve öğretmen bu davranışı, kaba kuvvetle yönetmeye çalışmıştır. Din eğitiminin kaynağı olan Sünnette, öğretmen olarak gönderilen Allah Resulü(S.A.), hiçbir şekilde kaba kuvvet kullanmadığ

56 | P a g e 
halde, dini anlatmakla yükümlü olan bu öğretmenin kaba kuvvet kullanması, din eğitiminde sünnetin uygulanmasında sorun olduğunun işaretini vermektedir. Kur'an Allah Resulü'nü "Allah'tan gelen bir merhamet sayesinde çevresindekilere karşı yumuşak huylu bir kişi(Al-i İmran: 159)" olarak anlatırken, O’nun için şu bilgiyi paylaşır: “ Andolsun ki, size kendi içinizden bir Peygamber gelmiştir. Sizin sıkıntıya düşmeniz ona pek ağır gelir. $O$ size çok düşkün, müminlere karşı çok şefkatli ve çok merhametlidir(Tevbe: 128).” Yönetici konumunda olan herkesin, özellikle ilim öğreten öğretmenlerin öğrencilere, çok düşkün, şefkatli ve sevecen olmaları Kur'an'ın gereğidir. Din eğitimi ile yükümlü olanların bu özelliklere sahip olmaları daha bir zorunluluk olarak açığa çıkmaktadır. Çünkü Allah Resulü(S.A.), bir numune-i imtisal(rol model) olarak bize, özellikle de din kültürü ve ahlak bilgisi öğretmenlerine, öğretmen-öğrenci ilişkilerinde şefkat ve merhameti canlı tutmayı önermektedir. İnsanlara, özellikle de öğrencilere şefkat ve merhametle yaklaşılması gerektiği bilgisine sahip olmak yetmez, bu bilginin davranış haline getirilmesi gerekir. Çünkü Allah Resulü(S.A.) öyle yapmıştı.

O’nun bu özelliğinden dolayı, Hz. Muhammed(S.A.) Müslümanların her türlü sorunlarını açabildikleri ve güven duydukları öğretmenleriydi(Özbek 1994:21). Onun öğretiminin genel yöntemi, tatlı sesiyle istiğrak ve vecd içinde önce Kur'an'dan ayetler okumak, sonra da bunları tefsir edip açiklamak ve kendisini dinleyenleri inanmaya davet etmekti(Özbek 1994: 22). Kendisini dinleyenler aynı zamanda onun öğrencileriydi. Görülüyor ki, öğrencileri ile arasında çok önemli bir güven ilişkisi söz konusu idi. Allah Resulü kibar ve yumuşak huylu olduğu için etrafindakilere asla kaba davranmazdı, kimseyi hor görmezdi(Tirmizi 2015: 2.Cilt: 249). Allah Resulü’ nün varisleri olduğuna inanan, özellikle din öğreten öğretmenlerin de, öğrencilerine kaba davranmamaları ve öğrencilerini hor görmemeleri gerekmektedir. İslami eğitim alanyazınında başta İbni Haldun olmak üzere, birçok yazar, şu ortak görüşe katılmaktadır. "Eğitim öğretim işlerinde öğrencilere, bilhassa küçük yaştaki çocuklara sert davranmak zararlıdır. Çünkü bu sert davranmalar, öğrencilerde kötü bir alışkanlık yaratır. $\mathrm{Bu}$ türlü eğitim öğrencinin ruh ve yaradılışına baskı yapıp onların neşesini, iş ve çalışma sevgisini yok eder ve onları tembelliğe ve kızgın ellerin kendilerine uzanmasından korkarak, yalana ve kötülüğe sevk eder. Git gide bu haller adet ve karakter haline gelir. Bundan dolayı öğretmen, anne ve babalar edep ve terbiye vereceğiz diye çocuklara sert davranmamalıdırlar(Haldun 1970:3.cilt: 160). Bu bilgilerin hayat tarzı haline gelmesi, öğretmenin dediği ile yaptığının aynı olması anlamına gelecektir.

Öğrencilerin bilgi eksikliği içinde olmaları normal olmasına rağmen, öğretmenin bu davranışı aşırı bir davranış kabul edip, sinirlenerek kaba kuvvet kullanması, ne pedagojik bulgulara, ne de sünnetin eğitim geleneğine uygun düşmektedir. Din kültürü ve ahlak bilgisi öğretiminde şiddetin ve kaba kuvvetin yeri olmaması gerektiği hususu, bütün İslami eğitim ve eğitim bilimleri alanyazınında var olmasına rağmen, uygulamada böylesi örneklerin yaşanıyor olması, din eğitiminin öğretim yöntemlerinde sorunların olduğunu göstermektedir.

Ben olsaydım, bilgi eksikliği olan öğrencilerin bilgilerini tamamlamak için onları özendirir, yardımcı olur ve belli bir süre tanıyarak, onlara firsat verirdim. Bilgi eksikliğinden dolayı kesinlikle kaba kuvvetin hiçbir zaman işe yaramayacağının bilincinde olarak, bu yolu hiçbir şekilde tercih etmezdim.

Siz olsaydınız ne yapardınız?

\section{ÖRNEK OLAY 2}

\section{Duayı Ezberleyemeyen Öğrenci}

İlkokul 6. Sınıfta din kültürü ve ahlak bilgisi dersi için, öğretmen, bir hafta önce, öğrencilerin bir dua ezberlemelerini istemişti. Ezberlerin dinleneceği ders saati geldiğinde, öğretmen, herkese surayla okutuyordu. Bir kız öğrenci duayı ezberleyememiști. Bu öğrenciye öğretmenimizin verdiği ceza, bütün öğrencilerin önünde feci bir şekilde dayak olmuştu. Bu dayak öğrencinin dine ve din kültürü öğretmenlerine karşı soğuk duruşun ilk kıvılcımı olmuştu. Ta ki, yeni bir din kültürü öğretmeni ile tanı̧sana kadar...

Duayı ezberleyememek, istenmeyen davranış olarak değerlendirilebilir. Öğrencilerin bazı konularda ezber yapmaları, onların hafizalarını güçlendirir. Örneğin bir şiir ezberleme, bir şarkı sözü ezberleme ya da bir dua ezberleme öğrencilerin hafızalarını önemli ölçüde kuvvetlendirir. Öğretmenin böyle bir ödevi vermiş olması, hem din eğitimine, hem de eğitimbilimlerine uygun bir davranış olarak değerlendirilmelidir.

Öğretmenin istenmeyen bir öğrenci davranışını şiddet kullanarak önlemeye çalışması, hele de din eğitiminde böyle bir davranışın kullanılması asla uygun olmaz. Bu örnek olayda da istenmeyen öğrenci davranışını yönetmeye çalışan, istenmeyen öğretmen davranışı ile karşı karşıyayız. Böylesi bir öğretmen davranışı, öğrencinin ezber yapma davranışını pekiştirmez, aksine, eğitime, öğrenmeye, dine karşı olumsuz bir tutum edinmelerine yol açar. Nitekim öğrenci, kendisinin dine ve din kültürü öğretmenlerine karş1 olumsuz bir tutum geliş̧irmesinin ilk kıvılcımı olarak, bu olayı göstermiştir. Din eğitiminde

57 | $P$ a g e 
istenmeyen bir davranışın şiddetle önlenmeye çalışılması, hiçbir şekilde uygun olmaz. Bu örnek olayda da din kültürü ve ahlak bilgisi öğretmeni, hem İslami eğitim uygulamalarına, hem de eğitim bilimleri verilerine aykırı davranarak, öğretmen-öğrenci ilişkilerinin olumsuzlaşmasına neden olmuştur.

Ben olsaydım, ezber yapan her öğrenciye "beş notu" verirdim; ezber yapamayan öğrenciye de not vermezdim. Böylece ödevini yapan öğrenciye ödül verirken, ezber yapmayan öğrenciye not vermezdim. $\mathrm{Bu}$ davranış, ezber yapmayan öğrencinin daha sonra "beş notu" alabilmek amaciyla da olsa, ezber yapmaya başlamasına yardımcı olacak ve bu işin tadına varacaktır. Burada öğretmen, öğretmen-öğrenci ilişkilerinde merhamet ve sevgiyi öncelemiş olacağından öğrenci, din kültürü ahlak bilgisi dersini ve öğretmenini sevmeye başlamış olacaktır. Sevginin egemen olmadığı sınıf içi ilişkilerinde, öğretmen de ögrenci de mutsuz olacaktır.

Siz olsaydınız, ne yapardınız?

\section{ÖRNEK OLAY 3}

\section{Din Kelimesinden Nefret Ettiren Din Kültürü ve Ahlak Bilgisi Öğretmeni}

Lise 1. Sınıf öğrencisiydim. Haftanın ilk günü, din kültürü ve ahlak bilgisi öğretmenimizle tanıştıktan sonra, öğretmenimiz; "Herkesin evinde ansiklopedi var, değil mi?" dedi. Sınıfın çoğunluğundan "evet" cevabı yükseldi. Öğrencilerden gelen olumsuz cevapları duymazlıktan gelen öğretmen; "Gelecek ders ansiklopediden "din" kelimesinin anlamını araştırarak gelin, dedi.

Hafta sonu, ilk ödevimi, yani din kültürü ve ahlak bilgisi ödevimi, ablamın "Lise 3 Din Kültürü ve Ahlak Bilgisi" ders kitabından yararlanarak yaptım. Dersin başlamasına 10 dakika kala sınıflarımızı doldurmuştuk. Sıralarımıza oturmuş, öğretmenimizi bekliyorduk. Öğretmen biraz sonra sınıfa geldi, onu ayakta selamladıktan sonra tekrar yerlerimize oturduk. Öğretmen yoklamayı aldıktan sonra tekrar yerlerimize oturduk. Öğretmen yoklamayı aldıktan sonra; "Geçen hafta verdiğim ödevi yaptınız mı?" diye sordu.

Öğrencilerin çoğu; "Evet” cevabını verdikten sonra, öğretmen tekrar şöyle dedi: "Defterlerinizi açın." Defterlerimizi açtık ve öğretmen kontrollerine başladı. Baktığı defterleri imzalamadan önce, her öğrenciye şöyle soruyordu: "Hangi ansiklopediden yazdın?"

Her ögrenci yararlandığı ansiklopedinin adını söylüyordu. Sıra bana geldi. Bana da aynı soruyu yöneltti. Ben de; “Ablamın Lise 3 Din Kültürü ve Ahlak Bilgisi kitabından yazdım.” Dedim. Öğretmen, birden kaşlarını çattı, sinirlendi ve sınıfa döndü; "Ben size, evinizdeki ansiklopediden yazacaksınız demedim mi?" diye gürledi. Sonra bana dönerek; "Hamsi gibi kafanı koparırım.” dedi. Ben neye uğradığımı ve ne yapacağımı şaşırmıştım. Hiçbir şey söylemeden, dersin bitmesi için gerekli olan, ömrümün en uzun 20 dakikasını, buğulu gözlerle beklemiştim. O günden sonra din derslerine girmemeyi, hatta Pazartesi hiç derslere girmemeyi bile düşünmeye başlamıştım. O günden sonra "din” kelimesi ne zaman bir yerde geçse, din dersi öğretmenine duyduğum nefret aklıma gelir olmuştu. Bu nefretim, ikinci dönem tanıdığım en sevecen, en hoşgörülü başka bir din kültürü ve ahlak bilgisi öğretmeni ile karşılaşıncaya kadar sürdü. $\mathrm{Bu}$ örnek olayda öğrencinin ödevi, öğretmenin istediği gibi yapmaması davranışı istenmeyen öğrenci davranış1 olarak değerlendirilmiş ve öğretmen tarafindan pedagojik hiçbir temele dayanmayan bir yöntemle öğrenciye tepki verilmiştir. Bu durumda evet bir sorun var, ama öğrenci değil, öğretmen sorun olarak görünmektedir. Öğretmenin öğrencilere ödev vermesi olağan bir iştir. Ancak buradaki din kültürü ve ahlak bilgisi öğretmeni, öğrencilerin bilgi edinmesini değil, kendi istediği kaynaktan bilgi edinmesini istemekte ve bunun üzerinde ssrarcı olmaktadır. Oysa bilgi çağında bilginin niteliği değiştiği gibi, bilgiye ulaşma yolları da değişmiştir. Hele bilgi çağında tek kaynaktan bilgi edinmenin artık hiçbir bilimsel tabanı kalmamıştır. Buradaki öğretmen, bilgi çağının öğretmeni gibi davranmamıştır. Bu öğretmenin davranışı, geleneksel öğretmen davranışı olarak değerlendirilebilir. Çünkü bilgi çağının öğretmeni olan lider öğretmen, bilginin kaynaklarını belirtir, ama tek kaynak üzerinde 1srarcı olmaz. Bu davranış öğrencilerin ezberci olmalarına zemin hazırlar. Bu öğretmenin ödev verme davranışı pedagojik olarak uygun görünmemektedir. Bu yanlış ödev verme davranışının yaptırımları da, çok daha olumsuz öğretmenlik davranışlarının ipuçlarını vermektedir. Neden tek kaynaktan ödev yapmadığını sinirli ve kızgın bir biçimde ifade ederek, öğrencinin motivasyonunu, şevkini ve gururunu kıran öğretmen, aynı zamanda öğrencinin “din” e ve din eğitimi verenlere karşı olumsuz bir tutum geliştirmesine sebep olmuş görünmektedir. Ne var ki kısa bir süre sonra bu öğretmenle taban tabana zıt başka bir öğretmenle tanışan öğrenci, din algısını tekrar düzeltmiştir.

Ben olsaydım, ödevi şöyle verirdim: "Din kelimesinin anlamını çeşitli kitap, ansiklopedi veya öğretmenlerden araştırarak, kendi cümlelerinizle ifade ediniz. Kesinlikle tek kaynak üzerinde 1srarc1 olmayacağım.” gibi, kaynaklar konusunda da seçici olmazdım. Bu olaydaki öğrenciyi, diğer öğrencilerden farklı kaynak kullandığı için azarlamak değil, takdir etmenin daha çok bilgi çağının öğretmenine uygun düşeceği açıktır. Bilgi çağının öğretmeni, bütün bilgi kaynaklarına açık olmalı, ancak

58 | $P$ a g e 
bütün kaynakları kullanırken eleştirel bir tutum sergilemelidir. Ben olsaydım, öğrencinin en kolay ulaşabildiği kaynağı eleştirel bir tutumla değerlendirmesine olumlu yaklaşırdım.

\section{ÖRNEK OLAY 4 \\ Din Kültürü ve Ahlak Bilgisi Dersini Yaşama Biçimini Sorgulayarak Değerlendiren Müfettis}

Alanımda çok iyi olduğuma olan inancım, yıllar geçtikçe daha da artıyordu. Artık öğretmenliğimiz onuncu yılını yaşıyordum. Birçok kez teftiş geçirdim. Bunun için müfettişlerin okula geldiğini öğrendiğim zaman, oldukça rahattım. Din kültürü ve ahlak bilgisi öğretmeniydim. Dördüncü derse girmiştik. Dersin 15 dakikası geride kalmıştı. Gelen giden henüz yoktu. Gerçi, çok da önemli değildi. Çünkü müfettiş gelecek diye dersimi özel bir biçimde işleyecek değildim; kendime güvenim tamdı. Projeksiyonu kurmuş, teknoloji eşliğinde dersimi işliyordum. Öğrencilerin derse aktif katılımı, beni daha da şevklendiriyordu. Biraz sonra kapı çaldı. Gelenin kim olduğunu tahmin etmem zor olmadı; beklediğim gibi, müfettiş geldi. Müfettişi karşıladıktan sonra, sınıfa dönerek, kendimden emin bir şekilde dersime devam ettim. Öğrencilerde fikirleri ve sorularıyla derse katılıyor, bana eşlik ediyorlardı. Netice itibariyle, yaşanan oldukça verimli bir ders süreciydi. Konunun sonuna gelmiştik. Müfettiş; "Hocam dersiniz bitti, sanırım." dedi. Ben de; "Evet, sayın müfettişim, ders bitti." dedim. Müfettiş; "Oldukça aktif bir ders süreci yaşadım sayenizde, size ve öğrencilerinize teşekkür ederim.” diye karşılık verdi.

Bu cümle, benim ve öğrencilerin çok hoşuna gitti, keyif aldık bu sözden. Ben de öğrencileri öven sözlerle konuşmayı sürdürdüm. Derslerde kullandığım farklı yöntem ve tekniklerin, verdiğim proje ve performans ödevlerinin nasıl da işe yaradı̆̆ını, büyük bir iştahla müfettişe anlatıyor, bu okulda çalışmaktan duyduğum mutluluğu ifade etmek için doğru cümleler seçmeye çalışıyordum. Bu cümleler bence müfettişi de memnun etmişti. Arkasından ağzımdan; "Sayın müfettişim, dilerseniz öğrencilere dualar, dini kavramlar veya bunların yorumları ile ilgili sorular sorabilirsiniz.” cümlesi çıktı. Müfettiş de; "Madem bu kadar özgüveni yüksek bir tavır ve duruş sergiliyorsunuz, öğretimsel anlamda birçok şeyi yaptığınıza inanıyorum, o zaman, izin verirseniz, dersinizin bir kısmı da ahlakı ilgilendirdiğinden bu boyutla ilgili size katkı sağlayayım." dedi. "Tabii, memnun olurum." diyerek karşılık verdim. Ahlak ile ilgili nasihat etmesini beklerken sınıfa şöyle bir soru yöneltti: "Çocuklar, bu sınıfta hiç küfretmeyen, arkadaşına lakap takmayan bir öğrenci gösterebilir misiniz bana?” Sınıf bir anda buz kesti. Sınıftan bir ögrrencinin ismi söylendi. Ona da bazı öğrencilerin itirazları gecikmedi. "Hayır, hocam, bana çok lakap takıyor, hiç ismimle çağırmıyor ve çok küfrediyor.” diye öğrenci itirazları sınıfta yükseldi.

Dersimden 100 alan öğrenciler, kısa ve basit bir ahlak dersinden sıfır çekmişlerdi. Bu, benim dersim için büyük bir yıkımdı. Ahlakın edebiyatını yapmışım, ama ahlaklı olmalarını sağlayamamışım. Bu duyarlılığı çocuklara kazandıramamışım. 10 Yıllık maslak hayatımda çok teftiş görmüştüm. Ama ilk defa böyle bir uygulama ile karşılaşmıştım. O kadar etkilenmiştim ki, sinirlerim boşaldı. Dersten sonra hüngür hüngür ağladım. Ama gerçekten bazı klişelerimin sorgulanması noktasında isabetli bir denetim geçirmiştim. Din kültürü ve ahlak bilgisi dersi öğretiminin, sadece bazı terimleri ve duaları ezberletmek, projeksiyon, vb. araç-gereçlerle, geniş katılımlı ders işlemek olmadığının farkındalığını yaşamam için bu uygulama benim ve kendi zümre başkanı olduğum öğretmenler için bir dönüm noktası mesabesindeydi. Bu örnek olayda da, işini sıra dışı yapan bir müfettiş ve işini çok iyi yapığını sanan bir din kültürü ve ahlak bilgisi öğretmeni var. Müfettiş, kitabi bilgileri test etmek yerine, bilgilerin ne kadar yaşam biçimi yapıldığına ilişkin değerlendirmelerde bulunarak, eğitimin, öğretimde ne kadar var olduğunu anlamaya çalışarak, din kültürü ve ahlak bilgisi öğretiminin ne kadar işlevsel olduğunu öğrenmiş görünüyor. Bu müfettiş davranışı, din kültürü ve ahlak bilgisi öğretmeninin din eğitimine farklı bakmasına, yani öğretmende farkındalık ortaya çıkmasına sebep olmuştur. Çağdaş eğitim denetiminin hedefi de öğretmenlerin işlerini daha iyi yapmalarına kılavuzluk etmektir. İşte bu örnek olayda ortaya çıkan durum da budur. İlk defa böyle bir denetim süreci yaşayan öğretmen, psikolojide önemli bir kavram olan "farkındalığı" bizzat yaşama imkânı bulmuştur. Din kültürü ve ahlak bilgisi öğretmeni de, iyi öğretmen olmanın, salt kitabi bilgileri öğretmekle olunamayacağını ilk kez anlamış görünüyor. Aynı zamanda, bu olaydaki din kültürü ahlak bilgisi öğretmeni, din öğretiminin nasıl işlevsel olabileceğinin ipucunu yakalamış görünmektedir. Din kültürü ahlak bilgisi öğretmeni, eğitimdeki uygulamaların daha çok dış görüntüyle ilgili olduğunun somut bir örneğini ortaya koymaktadır. Buradaki din kültürü ve ahlak bilgisi ögretmeni, bu denetim süreci ile de, din öğretmenin dış görüntü ile değil, dinin yaşam biçimi haline gelmiş olması ile mümkün olabileceğini ilk kez anlamış görünmektedir. Oysa din kültürü ve ahlak bilgisi, öğrencilerin bildiklerini hayata geçirmeye uygun bir yöntemle öğretilmesi gerekir. Bildiği bir bilgiyi davranışına yansıtamayan kişinin eğitimli kişi olmayacağı açıktır. Önemli olan bildiği ile amel etmesini bilen insanlar yetiştirmektir. Bu denetim süreci, buradaki din kültürü ve ahlak bilgisi öğretmenine bilmenin başka, bildiği ile amel etmenin bambaşka olduğunu öğrettiği görülmektedir.

Ben müfettişin yerinde olsaydım, onun gibi davranmaya çalışırdım. Çünkü müfettişin bu davranışı, bildiklerimizi davranışlarımıza aktarıp aktarmadığımızı test etmeyi amaçlıyordu ve bunu iyi test etti.

59 | P a g e

www.iiste.org 
Bildiklerimiz davranışlarımıza uymuyorsa, bunlar ancak bize yük olurlar. Öğretmen de müfettişten gerektiği dersi almış göründüğü için, onun yerinde olsam da aynı davranışı sergilemeye çalışırdım; o güne kadar geliştirdiğim ve önemsediğim öğretmenlik kalitemi masaya yatırarak yeni bir paradigma ile din kültürü ve ahlak bilgisi dersi öğretmeye çalışırdım.

Siz olsaydınız ne yapardınız?

\section{Sonuç Ve Öneriler}

Din kültürü ve ahlak bilgisi öğretmenlerinin öğretmen-öğrenci ilişkileri, daha çok geleneksel öğretmen davranışlarını örneklemektedir. Bu sonuç, bütün öğretmenler için geçerlidir. Bu sonuç, Osmanlı'dan kaynaklanan bir gelenekle ilişkili olabilir. Nitekim Osmanlı'da ana-babalar, çocuklarını hocaya teslim ederken elini öptürürler ve "eti senin kemiği benim" derlerdi. Bu sözle hocaya, çocuklarını dövebileceğini ifade etmiş olurdu(Akyüz, 2010: 90). Bu sözün esas anlamı şu olsa gerek: "Hocam ben sana güveniyorum; bu çocuğumu yetiştirmen konusunda tam yetkilisin. Yoksa "al bu çocuğu döv, geri kalanı bana yeter" asla değildir. Ne var ki, söz, bu haliyle değil, öğretimde öğretmenin șiddeti eğitim arac1 olarak kullanabilecekleri biçimiyle anlaşlagelmiştir. $\mathrm{Bu}$ nedenle geleneksel eğitimde dayak, eğitimin en önemli aracı olarak görülür, hoca da çocukları, tokatla, değnekle, falaka ile döverdi. Toplumda yaygın bir deyiş vardı: "Hocanın vurduğu yerde gül biter." Çocukların, üzerinde Kur'an okudukları rahlelere de İranlı Sadi’nin şu ünlü mısraının yazıldığı olurdu: Öğretmenin cefası, babanın şefkatinden daha iyidir(Akyüz 2010: 90-91). Böyle bir geleneğin günümüzdeki karşıllı̆̆1 olan din öğretiminin, bu geleneğin devamı olduğunu söylemek yanlış olmasa gerektir. $\mathrm{Ne}$ var ki bütün ögrretmenlerin genelde bu geleneğe uygun davrandıklarını söylemek doğruyu teyit etmek olacaktır.

Geleneksel eğitim, her tür eğitim çalışmasını yetke(otorite) ilkesine dayatan ve çocuğu toplumsal çevrenin kurallarına uymaya zorlayan bir eğitim. Daha çok geleneksel okuldan söz edilir. Karşıtı yeni eğitim ya da çağcıl eğitim( Öncül, 2000). Bilgi çağının öğretmeni, çağcıl eğitimin öğretmeni olarak anılır. Çağın gereklerine uygun davranmayan öğretmenler için "geleneksel öğretmen" tabiri kullanılır.

Eski mektepte adeta bir istibdat idaresi yürürlükte idi. Mektep hocass elinde değneği ve falakasıyla bir çocuk cemaatinin adeta bir padişahıymış gibi keyif başında hükmeder ve çocuk ruhunun tabii isyanlarını ancak sopa kuvvetiyle bastırabilirdi. Yeni mektepte sopanın yerine itimat ve muhabbet kaim oldu. Yeni mektebin sınıfları adeta cumhuriyetle idare edilir hissini verir. Her çocuk benliğine ve izzet-i nefsine sahiptir. Muallim müşfik ve hayırhah bir reis-i cumhur gibi onları korur, irşat eder, korkutmadan saydırır. Emrettiğini hissettirmez. Yeni mektepte artık sopaya değil, başka ceza ve mükafat vasıtalarına da ihtiyaç kalmiyor(Resimli Gazete, Sayı, 41, 14 Haziran 1341; Aktaran İ. Kara ve A. Birinci, 2005;447). Eski mekteple yeni mektebin zihniyetinde bir farklılı̆̆ı olmaması, yeni mektepte de eğitim bilimleri verilerine uygun olmayan davranış modellerinin yaşanıyor olmasına neden olmaktadır.

Cumhuriyet dönemine kadar geleneksel ve modern eğitim kurumlarında eğitim yapıldı. İki kurum da zaman zaman alabildiğine karşısındakine muhalefet ederken ve eğitim-öğretim yöntemleri bakımından farklılaşırken, bazen de birbirine yakınlaşmıştır. Ancak benzer özelliklerden birisi modern ve geleneksel okullardaki disiplin ve cezalandırma uygulamaları olarak görüldü. Tanzimat'ın ürünü modern okullar, siyasi iradenin kesin taraf olmasıyla, geleneksel mektepler karşısında bazı yazar, edip ve eğitimciler tarafindan yüceltilmiştir. Bu süreçte mahalle mekteplerine ve diğer geleneksel okullara karşı kesin bir önyargı oluşturulmuştur. Ancak dönemin farklı okullarındaki gündelik hayata ilişkin anılar bu keskinliği olabildiğince ortadan kaldırmakta ve bu kurumlar arasında pek çok ortak noktanın yaşatıldığını göstermektedir. Türkiye'de fiziksel cezaların terbiye yöntemi olarak algılanması, eğitimde dayağın gelenekselleşmiş bir yere sahip olması, dayağın kanıksanan bir davranış olarak algılanmasına ve fiziksel cezanın kamusal alanda meşru olarak kabul edilmesine neden olmuştur(Akyüz, 2015). Bu durum kültürümüzde şiddetin kanıksandığının göstergesi olarak değerlendirilebilir.

Din kültürü ve ahlak bilgisi öğretmenlerinin davranışlarını örnekleyen yukarıdaki örnek olaylar, din kültürü ahlak bilgisi öğretiminde öğrenci-öğretmen ilişkilerinin çağın değişen şartlarına uygun olmadığının ipuçlarını vermektedir. Din kültürü ve ahlak bilgisi İslami eğitimin hedefi olan erdemli insanlar yetiştirmede bu haliyle yetersiz kalmaktadır. Çünkü din kültürü ögretiminde salt kitabi bilgilerin öğrenilmesi üzerinde yoğunlaşılmakta, bu bilgilerin davranış haline gelip gelmediği üzerinde durulmadığ 1 görülmektedir. Salt kitabi bilgilerin aktarılmasına özen gösterilen bir ders formatına dönüşmüş olan din kültürü ahlak bilgisi dersinden erdemli insanların yetişmesi elbette zordur. Öğrencilere din kültürü ve ahlak bilgisinin kuramsal bilgilerini aktarmak ve kazandırmak yetmez, bu bilgileri bir yaşam biçimi haline getirmek gerekli olduğu halde bu örneklerdeki öğretimin buna hizmet etmediği anlaşılmaktadır. 


\section{Öneriler}

"Bilmek başka, bildiği gibi yaşamak bambaşka" sözünü hayata geçirmek, din kültürü ve ahlak bilgisi öğretmenlerinin en temel önceliği olmalıdır.

Din kültürü ve ahlak bilgisi öğretmenleri, İslami eğitimin gerecek yüzünü, çağın eğitim sisteminde somutlaştırmakla yükümlü olduklarının farkına varmaları için gerekli tedbirlerin alınması zorunludur. Din kültürü ve ahlak bilgisi öğretmenlerinin öğretmenlik kalitesi, İslami geleneğin gerçekleri ile eğitim bilimlerinin bulgularına uygun olacak şekilde geliştirilmelidir.

\section{Kaynakça}

Akyüz, E. (2015), Çocuk Hukuku ve Çocukların Hakları ve Korunması, Ankara: Pegem Yayınları

Akyüz, Y. (2010), Türk Eğitim Tarihi, Ankara: PEGEM Yayınları,

Güçlüol, K.(1985). Eğitim Yönetiminde Karar ve Örnek Olaylar, Ankara: Kadığlu Matbaası

Haldun, İ. Mukaddime, 3. Cilt.(Çev.Z. K.Ugan), İstanbul: Milli Eğitim Basımevi

Karasar, N.(1991). Bilimsel Araştırma Yöntemi. Ankara

Kara, İ. ve A. Birinci, (2005), Mahalle/Sibyan Mektepleri, İstanbul Dergâh Yayınları, "Resimli Gazete, Sayı, 41, 14 Haziran 1341"

Nisbet, J. \& J. Watt(1984). Contucting Small-Scale İnvestication İn Educational Management. London: The Open University

Oğuzkan, F.(1981). Eğitim Terimleri Sözlüğü, Ankara: TDK Yayınları

Okutan, M. (2015). Sınıf Yönetiminde Örnek Olaylar, Ankara: PEGEMA

Öncül, R. (2000), Eğitim ve Eğitim Bilimleri Sözlüğü, İstanbul: MEB Yayınları

Özbek, A.(1994). Bir Eğitimci Olarak Hz. Muhammed, Konya: Esra Yayınlar

Tirmizi(2015). Şemaili Şerif Şerhi, 2. Cilt, (Çev. M.Y.Kandemir), İstanbul 